Studia Źródłoznawcze, t. LVI

p-ISSN 0081-7147

e-ISSN 2451-1331

Ewa ZIELIŃSKA

Instytut Historii im. Tadeusza Manteuffla PAN

Warszawa

\title{
„Entretiens" Stanisława Augusta z ambasadorem rosyjskim Ottonem Magnusem von Stackelbergiem i „Mémoires” ostatniego króla Rzeczypospolitej
}

\begin{abstract}
Zarys treści: W artykule zaprezentowano jedno z ważniejszych źródeł do dziejów panowania Stanisława Augusta, jakim są zapisy rozmów króla z ambasadorem rosyjskim Ottonem Magnusem von Stackelbergiem z lat 1773-1779. Szczegółowo omówiono czas, miejsce i sposób powstania tego źródła oraz zestawiono je z obejmującym ten sam okres fragmentem „Mémoirs” ostatniego króla. „Entretiens” stanowiły szkielet chronologiczny i faktograficzny, na którym król bazował, pisząc „Mémoirs”, dlatego mogą być one wykorzystane do oceny wiarygodności królewskich pamiętników. Odkrycie nieznanego dotychczas czystopisu „Entretiens” wśród materiałów rewindykowanych z Rosji skłania do poszukiwań w archiwach rosyjskich kolejnych roczników „Entretiens”, które król musiał mieć w Petersburgu, pracując nad kolejnymi tomami swoich wspomnień.
\end{abstract}

\begin{abstract}
The article presents one of the most important primary sources on the history of reign of King Stanislaus Augustus in the form of notes of the king's talks with the Russian Ambassador Otto Magnus von Stackelberg held in 1773-1779. There is a detailed analysis of the time, place and manner in which the source was created, together with its comparison with a fragment of the king's Mémoirs, spanning the same period of time. The Entretiens made a chronological and factual frame for the king's Mémoirs, and for this reason they could be used to assess the reliability of Stanislaus Augustus' memoirs. The discovery of an unknown so far clean copy of the Entretiens among the materials repossessed from Russia induces us to look in Russian archives for other tomes of the Entretiens, which the king had to have with him in Saint Petersburg, when he was working on successive volumes of his memoirs.
\end{abstract}

Slowa kluczowe: „Mémoires” Stanisława Augusta, Otton Magnus von Stackelberg, „Entretiens” Stanisława Augusta, stosunki polsko-rosyjskie w XVIII w., źródła do panowania Stanisława Augusta

Keywords: Stanislaus Augustus' Mémoires, Stackelberg, Stanislaus Augustus' Entretiens, Polish-Russian relations in the $18^{\text {th }}$ century, sources on King Stanislaus Augustus' reign

Jednym z ważniejszych źródeł do dziejów panowania Stanisława Augusta są relacje z rozmów prowadzonych przez króla lub osoby przez niego wyznaczone z różnymi osobistościami życia politycznego ówczesnej Rzeczypospolitej. W przeważającej liczbie byli to dyplomaci obcych państw przebywający na warszawskim dworze. Owe „Entretiens” (nazwa, jaką nadano im w Gabinecie) - w większości przypadków spisywane w języku francuskim - mogą kojarzyć się z popularnym w XVIII w. gatunkiem literackim, lecz W rzeczywistości nie były tworzone z myślą o ich udostępnianiu szerszej publiczności. Z całą pewnością pełniły rolę ważnego dokumentu wytwarzanego w królewskim Gabinecie w celach dokumentacyjnych ${ }^{1}$.

1 Jako pierwszy osobną publikację poświęcił królewskim „,rozmowom” Stanisław Wasylewski, który we wstępie do książki o nich skupił się bardziej na analizie treści zachowanych zapisów od strony ich wartości literackiej; Stanisław August, Rozmowy z ludźmi, wybór i oprac. S. Wasylewski, przedm. A.M. Skałkowski, Lwów 1930. Większość rozmów opublikowanych 
Stan zachowania „Entretiens” Stanisława Augusta trzeba ocenić jako wysoce niezadowalający. Dzięki fundamentalnej pracy Piotra Bańkowskiego o archiwum Stanisława Augusta ${ }^{2}$ posiadamy sporą wiedzę na temat zapisów rozmów, które zostały sporządzone, lecz nie zachowały się do dnia dzisiejszego 3 . Po podziale królewskiego archiwum większość najcenniejszych materiałów, które znalazły się w posiadaniu księcia Stanisława Poniatowskiego, została wywieziona do leżącego pod Wiedniem zamku Lichtenstein i tam najprawdopodobniej spłonęła w XIX w. ${ }^{4}$ Wśród wywiezionych przez Poniatowskiego „Entretiens” P. Bańkowski wymienia rozmowy z posłem austriackim baronem Karlem Revitzkim (1772-1779)5, tomy „Entretiens” z rosyjskim ambasadorem Mikołajem Wasiliewiczem Repninem, posłem duńskim Armandem de Mestral de Saint Saphorinem, Jerzym Flemmingiem, Władysławem Gurowskim i zapewne Ignacym Massalskim (1767-1771) ${ }^{6}$, indeks rzeczowy do „Entretiens” z Repninem zatytułowany „Sujets traités dans les différents entretiens que le Roi a eu avec le pr. Repnin dans le cours des années 1767-1771" ". Dalej w spisie woluminów otrzymanych i wywiezionych przez księcia Stanisława Poniatowskiego wymieniono rozmowy z posłem rosyjskim Michaiłem Nikityczem Wołkońskim ${ }^{8}$ ( 2 tomy z lat 1769-1771; pewne pojęcie o ich zawartości daje ekstrakt z nich zachowany w BCzart., sygn. 939), z posłem rosyjskim Kasparem von Saldernem 9 (3 tomy z lat 1771-1772), ambasadorem rosyjskim Ottonem Magnusem von Stackelbergiem ${ }^{10}$ (9 tomów z lat 1772-1789), głównodowodzącymi wojskami rosyjskimi w Rzeczypospolitej generałami Aleksandrem Iliczem Bibikowem i Abrahamem Iwanowiczem Romaniusem ${ }^{11}$ (1 tom z lat 1772-1779) oraz z nuncjuszami Antonio Viscontim, Angelo Durinim, Giuseppe Garampim i zapewne Giovannim Archettim (1 tom z lat 1765-1778) ${ }^{12}$. Z zachowanych „Entretiens” P. Bańkowski wymienia te z posłem pruskim Gédéonem Benoît ${ }^{13} \mathrm{z}$ lat 1772 -1776 (BPAU/PAN, sygn. 1648), pruskim generałem Rupertem Scipionem Lentulusem (lata 1773-1774, tamże), ekstrakty rozmów z Garampim i Archettim z lat 1772-1778 (BCzart., sygn. 961) oraz przede wszystkim ze Stackelbergiem z lat 1773-1779 (BPAU/PAN, sygn. 1649). Te ostatnie właśnie interesować nas będą w dalszej części niniejszego artykułu.

Zapis rozmów, choć bardziej precyzyjnie należałoby użyć słowa: kontaktów Stanisława Augusta ze Stackelbergiem, zachował się jedynie połowicznie. W przytoczonego wyżej zestawienia opracowanego przez P. Bańkowskiego wynika, że wraz z innymi materiałami przejętymi przez ks. Stanisława Poniatowskiego utraciliśmy zbiór 9 tomów „Entretiens” z rosyjskim ambasadorem, obejmujących cały okres jego pobytu w Rzeczypospolitej, lecz jednocześnie zachowały się zapisy tych rozmów z lat 1773-1779. Pierwszą kwestią, którą należałoby rozważyć, jest pytanie o to, co właściwie się zachowało? Początkowo wydawało się, że rękopis z BPAU/PAN o sygn. 1649 mógł być późniejszą kopią zaginionego

w tej antologii była wcześniej znana takim badaczom jak Walerian Kalinka, Henryk Schmitt, Szymon Askenazy, Bronisław Zalewski czy Kazimierz Morawski, co autor wyboru wyraźnie odnotował. Niedrukowane rozmowy pochodzą z rękopisu 799 Biblioteki Czartoryskich w Krakowie.

2 Piotr Bańkowski podjął się trudu odtworzenia zniszczonego w czasie II wojny światowej inwentarza archiwum ostatniego władcy Rzeczypospolitej autorstwa Jana Baptysty Albertrandiego, którego Stanisław August powołał na kustosza swojego archiwum w pierwszej połowie 1794 r.; tenże, Archiwum Stanisława Augusta. Monografia archiwoznawcza, Warszawa 1958, s. 21. O losie inwentarza zob. tamże, s. 145.

3 O ich losie i rozproszeniu zob. tamże, s. 93, 118-125.

${ }^{4}$ Tej części archiwum Stanisława Augusta bezskutecznie poszukiwał Emmanuel Rostworowski, o czym wspomniał w artykule Edukacja ostatniego króla (1765-1772), w: tenże, Popioły i korzenie. Szkice historyczne i rodzinne, Kraków 1985, s. 61-62.

5 P. Bańkowski, Archiwum Stanisława Augusta, s. 244.

${ }^{6}$ Tamże, s. 256.

7 Tamże.

${ }^{8}$ Tamże, s. 257-259

9 Tamże, s. 259 n.

10 Tamże, s. 260 n.

11 Tamże, s. 262.

12 Tamże, s. 300. Archettiego Bańkowski nie wymienia, ale skoro wspomniany tom „Entretiens” obejmował rozmowy z nuncjuszami spisane w latach 1765-1778, to zapewne były tam zanotowane również spotkania króla z Archettim, ten przebywał bowiem w Rzeczypospolitej jako nuncjusz w latach 1776-1784.

${ }^{13}$ P. Bańkowski, Archiwum Stanisława Augusta, s. 266 n. 
oryginału, jednak bliższa analiza struktury tego źródła wskazuje na to, że jest to minuta „Entretiens” ze Stackelbergiem, z której po zaakceptowaniu jej treści przez króla przygotowywano czystopisy kolejnych roczników. Charakter omawianego źródła potwierdza notatka umieszczona na ostatniej karcie zapisu rozmów z 1774 r.: „les minutes remises au roi le 24 janvier $1775^{\prime 14}$. Sam rękopis składa się z 14 zszytych razem zeszytów posiadających odrębną numerację, o zmiennej liczbie kart, wahającej się od 12 do 22. Pierwszy z zachowanych zeszytów nosi numer $5 / 5$, kolejne zaś oznaczone są numerami od 5 do 10 i obejmują okres od połowy maja 1773 do końca 1776 r. Występowanie dwóch zeszytów o podobnej numeracji - 5/5 i 5 - wynikało ze sposobu redagowania omawianego źródła w Gabinecie, o czym więcej piszę w dalszej części artykułu. Kolejne trzy zachowane roczniki „Entretiens” z BPAU/PAN, sygn. 1649 nie kontynuują wcześniejszej numeracji zeszytów, lecz każdorazowo po zakończeniu kolejnego rocznika rozpoczynają numerację od początku: rok 1777 obejmuje zeszyty nr 1 i 2, 1778 - zeszyty nr 1, 2, 3, a 1779 - zeszyty nr 1 i 2 . Ostatni zachowany zeszyt urywa się w połowie grudnia 1779 r. Nie jest to jak się wydaje - efekt późniejszego zdekompletowania źródła. Brak ostatnich kilku rozmów z 1779 r. wynikał z bardziej prozaicznej przyczyny. W tym miejscu po prostu skończył się 20-kartkowy zeszyt, a kilka ostatnich rozmów z 1779 r. wpisanych zostało do nowego zeszytu, zawierającego początek następnego roku, który się nie zachował. Podobna sytuacja miała miejsce na przełomie lat 1778 i 1779. Tu także ostatnia zapisana rozmowa, która kończyła zeszyt nr 3 z 1778 r., nosząca datę 17 grudnia, nie była ostatnią z tego roku. Już po karcie tytułowej rozpoczynającej „Entretiens” z 1779 r., jednocześnie będącej początkiem nowego zeszytu, znajduje się rozmowa z 23 XII 1778, opatrzona numerem 1. Co ciekawe, następna zanotowana w tym zeszycie „rozmowa"15 z 2 stycznia ma również numer 1.

Wszystkie zachowane do dnia dzisiejszego „Entretiens”, także te z rosyjskim ambasadorem, miały podobną strukturę wewnętrzną. Każda rozmowa króla, bądź jakakolwiek inna forma kontaktów króla i osób do tego upoważnionych z ważnymi osobistościami życia politycznego Rzeczypospolitej, znajdowała swoje odzwierciedlenie w źródle w postaci osobnego numeru z zaznaczoną datą dzienną. Jeśli informacja zawarta pod danym numerem dotyczyła jednego zagadnienia, nie dodawano dodatkowych elementów porządkujących treść, lecz jeżeli w czasie rozmowy król i ambasador omawiali kilka spraw, wówczas tekst dzielono na akapity, a na lewym marginesie dopisywano kolejne litery alfabetu, tak aby układ „Entretiens” był bardziej czytelny. Ułatwiało to również późniejsze tworzenie indeksów rzeczowych i sprawne odnajdywanie potrzebnych informacji. Czasami nie notowano daty, a jedynie numer, lecz w tym przypadku adnotacja przeważnie nie dotyczyła kolejnego spotkania, lecz informowała np. o przekazaniu jednej ze stron pewnych dokumentów bądź odnosiła się do wydarzeń wiążących się w ten czy inny sposób z szeroko pojmowanymi relacjami pomiędzy królem i ambasadorem. I tak pod nr. 55 z września 1774 r. znajdujemy wiadomość o wydaniu marszałkowi nadwornemu litewskiemu Władysławowi Gurowskiemu asygnacji na 3 tys. dukatów płatnych ze skarbu koronnego ${ }^{16}$, kilka kart dalej zaś, pod nr. 58, również z września 1774 r., zanotowano jedynie „Projet sur les starosties et les biens royaux". Często odnotowywano w ten sposób przekazywanie ambasadorowi nowin, które nadchodziły do króla z innych stolic europejskich za pośrednictwem jego stałych, nieformalnych czy okazjonalnych informatorów ${ }^{17}$. Zdarzało się również, że jedną datą opatrywano kilka kolejnych numerów „Entretiens”. Pod 4 X 1778 znajdujemy aż cztery kolejne numery: nr 97 zawierający „,rapport du grand chancelier de la Couronne”, nr 98 - „entretien du Roi avec l'ambassadeur”, nr 99 - „lettre de l'ambassadeur au Roi” oraz nr 100 - „entretien du Roi avec l'ambassadeur”. Mamy tu zatem aż cztery rodzaje „aktywności” w relacjach króla ze Stackelbergiem, które dotyczyły kwestii związanych z uzgodnieniem kandydatur osób przewidzianych do zasiadania w Radzie Nieustającej, czym miał się zająć obradujący wówczas

14 BPAU/PAN, sygn. 1649, k. 46v.

15 W tym przypadku była to wymiana biletów pomiędzy królem i Stackelbergiem.

16 BPAU/PAN, sygn. 1649, „Assignation de 3 mille ducats donnée au maréchal Gurowski sur le Trésor de la Couronne”, k. 39v. Wydaje się, że powodem odnotowania tego faktu w „Entretiens” króla ze Stackelbergiem było to, że wymieniona suma została obiecana Gurowskiemu na wyraźne życzenie Stackelberga.

17 Tamże, „Nouvelles de Berlin du 19 septembre et de Saxe du 20 septembre communiquées à l'amb[assadeur]”, k. 138v. 
$\operatorname{sejm}^{18}$. Pierwszy ze wspomnianych numerów opatrzonych datą 4 X 1778 to relacja z rozmowy, którą przeprowadził z ambasadorem kanclerz wielki koronny Andrzej Młodziejowski, a której treść przekazał królowi, drugi to relacja z bezpośredniego spotkania króla ze Stackelbergiem, dalej znajduje się krótka notatka z treścią listu, który ambasador przesłał do króla wraz z obiecaną we wspomnianej powyżej rozmowie listą osób przewidzianych do zasiadania w Radzie Nieustającej. Ostatnia adnotacja z 4 października dotyczy ponownie ,spotkania” króla z ambasadorem, ale w tym przypadku tytuł ,entretien du Roi avec l'ambassadeur" nie odzwierciedla rzeczywistości, ponieważ spotkanie odbyło się w szerszym gronie: poza królem i Stackelbergiem brali w nim udział także Andrzej Mokronowski, biskup płocki Michał Poniatowski oraz wojewoda kaliski August Sułkowski.

Jak już wspomniałam, minuty „Entretiens” dotyczących jednego roku były przesyłane królowi w celu ich sprawdzenia i dokonania ewentualnych poprawek. Poza $1776 \mathrm{r}$. zachowały się adnotacje pozwalające określić czas powstania kolejnych roczników „Entretiens”. I tak rozmowy z 1774 r. przesłano królowi do zaakceptowania już 24 I 1775, kolejny rocznik trafił do rąk króla dopiero 16 VII 1776, a rocznik 1777 był gotowy dopiero 13 XII 1778. Być może na tak długi czas weryfikacji minuty wpływ miały prace związane z przygotowaniem sejmików i samym sejmem. Ostatnie znane roczniki przekazano królowi do akceptacji 3 IV 1779 (z 1778) i 14 V 1780 (z 1779). Stanisław August niezmiernie rzadko dokonywał zmian w przesłanym tekście i były to wyłącznie poprawki stylistyczne bądź uzupełnienia brakujących słów ${ }^{19}$. Jak jednak powstawała minuta „Entretiens”? Z całą pewnością możemy powiedzieć, że nie była to praca jednej osoby, lecz przynajmniej kilku. Świadczą o tym różnice w charakterze pisma występujące w tekście. Na niektórych kartach występują aż trzy różne dukty, co każe domniemywać, że sama minuta powstawała na bieżąco bądź w niewielkim odstępie czasowym od opisywanych zdarzeń. Przykładowo rozmowa nr 38 z 27 VII 1776 sprawia wrażenie zredagowanej aż w czterech etapach przez trzy różne osoby $^{20}$. Punkty od A do H i początek punktu J zostały napisane jedną ręką, potem następują dwa zdania wyodrębnione specjalnymi liniami poziomymi, które z całą pewnością napisała inna osoba. Koniec punktu $\mathrm{J}$ i pierwsze dwa zdania punktu $\mathrm{M}$ to prawdopodobnie znów ta sama ręka co na początku, ale już kontynuację punktu $\mathrm{M}$ aż do końcowego punktu $\mathrm{P}$ napisał ktoś trzeci. Ta rozmowa należy jednak do wyjątków, przeważnie jedna osoba pisała kilka rozmów z rzędu. Jak zatem mogło wyglądać przygotowywanie „Entretiens”? W „Mémoires” Stanisława Augusta znajdujemy adnotację, która wskazywałaby, że król był jedną z osób tworzących na bieżąco przynajmniej część zapisów znajdujących się w „Entretiens”. W tomie ósmym swoich wspomnień władca, przywołując rozmowę ze Stackelbergiem z 21 X 1778, opracowaną na podstawie relacji zamieszczonej w „Entretiens”, wprowadził ją słowami: „il paroît nécessaire d'insérer ici l'extrait des notes que le Roi tenoit journellement”"21. Mamy tu zatem potwierdzenie przypuszczeń, że Stanisław August część rozmów mógł notować osobiście, a przekazane przez niego notatki były wpisane do prowadzonych w Gabinecie zeszytów „Entretiens”. Stąd również mogły wziąć się dość często obserwowane w źródle zmiany charakteru pisma. Być może istniała osoba odpowiedzialna za uzupełnianie przekazywanych przez króla bądź kogoś z sekretarzy tworzonych na bieżąco notatek czy streszczanie królewskiej korespondencji z ambasadorem, ale wspomniane wyżej przykłady różnego charakteru pisma skłaniają do mniemania, że część zapisów wprowadzali kopiści niezajęci w danym momencie innymi pracami w Gabinecie.

Nie wydaje się, aby całość tekstu składała się z notatek pochodzących od króla. Możemy przypuszczać, że spod pióra Stanisława Augusta wyszły zapisy wszystkich tych rozmów, które na stronach „Entretiens" mają formę dialogu. Jest ich w sumie 15 i, co ciekawe, pojawiają się w zasadzie w dwóch okresach. Pierwszy to 1775 r. już po zakończeniu obrad sejmu rozbiorowego, kiedy to mamy dwie rozmowy w formie dialogu z 14 i 15 maja, jedną z 11 lipca i aż pięć z okresu od 26 października do

\footnotetext{
18 Więcej informacji na ten temat zob. W. Filipczak, Sejm 1778 roku, Warszawa 2000, s. 159 n.

19 W „Entretiens” z 1779 r. w rozmowie nr 52 król nadpisał nad linią: „de l'évêque”, ponieważ bez tych słów zdanie brzmiałoby absurdalne: „Le prince évêque de Płock a répondu qu'il fallait attendre le retour de l'évêque de Livonie pour concerter à la Commission d'éducation les moyens de satisfaire en partie aux demandes dessus ex-jésuites”, BPAU/PAN, sygn. 1649 , k. 175.

20 Tamże, k. 77v-79.

${ }^{21}$ Stanislas Auguste, Mémoires, wyd. A. Grześkowiak-Krwawicz, D. Triaire, Paris 2012, s. 771.
} 
30 grudnia tego roku, wreszcie bliską im czasowo rozmowę z 3 I 1776. Dalej następuje przerwa aż do 29 IX 1777, kiedy to - do 21 grudnia tr. - ponownie aż pięć rozmów zostało zanotowanych w formie dialogu. Ostatnia rozmowa w takiej formule pomiędzy królem i Stackelbergiem odbyła się 24 II 1778. W 1779 r. nie odnotowano już żadnej. Trudno ustalić, skąd taka kumulacja. Być może jedynie w tych kilkunastu przypadkach Stanisław August rozmawiał z ambasadorem bez świadków, a być może rolę grała tu chęć upublicznienia części rozmów albo zamieszczenia ich w pamiętnikach, których pierwsze trzy tomy król zredagował w latach 1771-177522.

Zatem początkowo „Entretiens” miały charakter rzeczowych i dość krótkich notatek, by z czasem przybrać formę coraz bardziej rozbudowanych i szczegółowych relacji z kontaktów króla z ambasadorem. Wydaje się, że Stanisławowi Augustowi w czasie spotkań ze Stackelbergiem, które czasami odbywano w szerszym gronie, towarzyszyła osoba odpowiedzialna za sporządzenie szczegółowego zapisu ich przebiegu.

Obok relacji ze spotkań króla, w „Entretiens” odnotowywano również rozmowy, które na polecenie Stanisława Augusta odbywały z ambasadorem inne osoby. Pierwsze zachowane zapisy pochodzące z maja 1773 r., czyli z pierwszych miesięcy obrad sejmu delegacyjnego 1773-1775, dowodzą, że funkcję pośredników pełnili kanclerz wielki koronny Andrzej Młodziejowski i konsyliarz królewskiego Gabinetu Piotr Maurycy Glayre. W czasie pobytu Glayre’a w Paryżu jego miejsce zajął gen. Jan Komarzewski. Wydaje się całkiem prawdopodobne, że tak Glayre, jak i Komarzewski - jako osoby zaufane - mogli być stale obecni przy rozmowach króla i ambasadora również w charakterze protokolantów. W przechowywanych w Bibliotece Czartoryskich protokołach niektórych rozmów z Saldernem odnotowano jako jednego z uczestników właśnie Glayre’a ${ }^{23}$. Na obecność sekretarza, którego zadaniem było protokołowanie rozmów prowadzonych przez króla, oraz na to, że nie był on Polakiem wskazuje liczba błędów w zapisach nazw własnych czy też przekręceń w zapisie nazw polskich urzędów, które nie miały odpowiedników w języku francuskim. Na karcie nr 49 w notatce nr 18 z 26 III 1775 spotykamy dwie różne formy zapisu nazwiska Sanguszko: Jérôme Zangusko i Janus Zangouszko, natomiast w zapisie nr 25 z 10 IV 1775, w którym Benoît „,recommande pour le Conseil Permanent Jaconski²4, Dzirbitzki²5, le castellan de Genes ${ }^{26}$ et Jinieff'”27, mamy całą serię nazwisk w zapisie świadczącym o tym, że autorem notatki był obcokrajowiec, który zapisywał je ze słuchu, co szczególnie widoczne jest w przypadku ostatniego nazwiska „Jinieff” - „Żyniew”. W „Entretiens” prawie nigdy nie odnotowywano obecności innych osób podczas spotkań króla z ambasadorem, jedynie kontekst pozwala takie osoby wychwycić. Ze spotkania Stanisława Augusta ze Stackelbergiem 17 XII 1778 sporządzono bardzo szczegółową relację, dzięki której mamy pewność, że brał w niej udział również marszałek nadworny koronny Franciszek Rzewuski ${ }^{28}$. Podpunkt J powyższej relacji rozpoczyna się od słów: „Le maréchal Rzewuski étant sorti”, kolejny zaś - K - od słów: „Le maréchal étant rentré”. W tym czasie Stackelberg zdążył użyć wobec Rzewuskiego określenia „blanc-bec” (smarkacz, żółtodziób), a zrobił to w kontekście pozycji Rzewuskiego w relacjach z Adamem Czartoryskim i bawiącym wówczas w Warszawie Mikołajem Repninem.

Ciekawy przyczynek do analizy sposobu, w jaki redagowano „Entretiens”, stanowią wpisy z okresu od maja do końca 1773 r. Zostały one zebrane w dwóch osobnych zeszytach noszących nr. 5/5 i 5. W każdym zamieszczono w kolejności chronologicznej notatki, które wzajemnie się zazębiają i uzupełniają. Przykładowo zeszyt 5/5 rozpoczyna się od nr. 38 z 17 maja i znajdują się w nim kolejno nr. 39 i 40, ale nr 41 znajduje się w zeszycie 5, nr 42 „Entretiens” zapisano ponownie w zeszycie 5/5, a kolejne dwa numery - 43 i 44 - ponownie w zeszycie 5 . Z czego mogło to wynikać? Interesującą wskazówkę znajdujemy na lewym marginesie pierwszej strony zeszytu 5, w miejscu, gdzie zaznaczono - zapewne przy

\footnotetext{
22 Tamże, s. 25-27.

${ }^{23}$ BCzart., sygn. 939, „Sujets des entretiens du roi avec l'ambassadeur mons. Saldern”, s. 547-587.

${ }^{24}$ Prawdopodobnie chodzi o Stanisława Gadomskiego, podkomorzego sochaczewskiego,

${ }^{25}$ Szymon Dzierzbicki, kasztelan brzeziński.

26 Józef Starzeński, kasztelan gnieźnieński.

${ }^{27}$ Mateusz Żyniew, starosta berznicki.

${ }^{28}$ BPAU/PAN, sygn. 1649, „Entretiens”, nr 158, k. 156.
} 
tworzeniu czystopisu „Entretiens” za rok 1773 - aby nr. 38, 39 i 40 szukać w zeszycie 5/5. Czytamy tam: „Vid. Cayer 5/5. C'est à dire ce qui a été traduit du polonois par Konarski” ${ }^{29}$. Kolejną wskazówkę na temat tworzenia „Entretiens” przynosi analiza treści zapisów znajdujących się we wspomnianych zeszytach. Pierwszy z nich $(5 / 5)$ w przeważającej części zawiera informacje dotyczące przebiegu prac sejmu i Delegacji, które król otrzymywał za pośrednictwem marszałka sejmu rozbiorowego Adama Ponińskiego i kanclerza Andrzeja Młodziejowskiego. Ten ostatni często informował króla o planach i oczekiwaniach Stackelberga wobec jego osoby. Drugi zeszyt - oznaczony nr. 5 - jest wypełniony zapisami bezpośrednich rozmów Stanisława Augusta z ambasadorem oraz relacjami Piotra Maurycego Glayre'a ze spotkań, które odbył ze Stackelbergiem na polecenie króla. Zatem zeszyt 5/5 zawiera materiały przygotowane w Gabinecie w celu uzupełnienia właściwych „Entretiens”, tak aby w jednym miejscu znalazły się wszystkie najistotniejsze kwestie związane z relacjami polsko-rosyjskimi. Ponieważ nie zachowały się wcześniejsze zeszyty, nie wiemy, czy praktyka uzupełniania zapisów rozmów $\mathrm{z}$ ambasadorem o informacje dotyczące stosunków polsko-rosyjskich i innych działań podejmowanych przez Stackelberga była stosowana wcześniej. Czy obok zeszytu 1 nie istniał zeszyt 1/1? Jednak sam fakt dokonania tak istotnych uzupełnień świadczy o randze tego źródła. Uzasadnionym jest uznanie „Entretiens” Stanisława Augusta ze Stackelbergiem za jedno z najważniejszych źródeł do badań stosunków polsko-rosyjskich. Brak w kolejnych latach zeszytów uzupełniających świadczy o tym, że od 1776 r. zaczęto dbać w Gabinecie o to, aby „Entretiens” króla ze Stackelbergiem zawierały nie tylko streszczenia rozmów władcy z ambasadorem rosyjskim, lecz również inne informacje istotne dla relacji polsko-rosyjskich. Należy jedynie żałować, że dokumentacja wzajemnych relacji Stanisława Augusta i Stackelberga nie zachowała się w całości.

Zgodnie z ustaleniami P. Bańkowskiego wszystkie czystopisy „Entretiens” zostały wywiezione przez księcia Stanisława Poniatowskiego do zamku Lichtenstein pod Wiedniem, gdzie uległy zniszczeniu. W trakcie prac nad edycją „Entretiens” Stanisława Augusta ze Stackelbergiem z lat 1773-1775 udało się odnaleźć w polskich archiwach trzy czystopisy wcześniej niełączone z rękopisem z BPAU/PAN, w tym jeden wykraczający poza rok 1779. Pierwszy czystopis, obejmujący rok 1777, zidentyfikowała dr Dorota Dukwicz. Znajduje się on w Bibliotece Czartoryskich (rkps 961) i został błędnie opisany w inwentarzu opracowanym przez Stanisława Kutrzebę $e^{30}$. Zamiast roku 1777 podano tam 1771, a przecież wówczas w Warszawie przedstawicielem dyplomatycznym Katarzyny II był Michaił Nikitycz Wołkoński, a od kwietnia 1771 r. - Kapsar von Saldern. P. Bańkowski nie mając w ręku oryginału, a posiłkując się jedynie inwentarzem, powielił powyższy błąd ${ }^{31}$. Zupełnie niełączony dotychczas z rękopisem z BPAU/PAN o sygn. 1649 czystopis „Entretiens” Stanisława Augusta ze Stackelbergiem udało mi się odnaleźć w AGAD w zespole: Archiwum Koronne Warszawskie, dział: rosyjskie, 57/33, gdzie rękopis ten opisano jako: „Wyciągi z korespondencji ambasadora rosyjskiego ze Stanisławem Augustem, królem polskim" (w okresie od 23 XII 1778 do 4 I 1780). Jest to kompletny zapis rozmów z 1779 r., tym cenniejszy, że zawiera cztery ostatnie numery „Entretiens”, których brakuje w rękopisie krakowskim². Czystopis „Entretiens” z 1779 r. nie ma na stronie tytułowej sygnatury nadawanej przez królewskiego archiwistę ks. Jana Baptystę Albertrandiego. Nie oznacza to jednak, że nie był on częścią królewskiego archiwum. Na ostatni fragment „Entretiens” Stanisława Augusta ze Stackelbergiem, obejmujący okres od 1 stycznia do 18 maja 1781 r. (odpowiednio numery od 1 do 48), dotychczas niewykorzystywany przez badaczy, natrafiłam w AGAD, w zespole: Archiwum Królestwa Polskiego, pudło 90, k. III,

\footnotetext{
29 Zapewne chodziło o pochodzącego z kalwińskiej szlachty Rafała Kazimierza Konarskiego, ur. ok. 1749 r., który, zgodnie z ustaleniami Marii Rymszyny, w latach 1779-1786 mógł pełnić w królewskim Gabinecie funkcję kopisty; por. S. Konarski, Szlachta kalwińska w Polsce, Warszawa 1936, s. 136; M. Rymszyna, Gabinet Stanisława Augusta, Warszawa 1962, s. 184.

${ }^{30}$ Catalogus codicum manu scriptorum Musei principium Czartoryski Cracoviensis, t. 2, oprac. S. Kutrzeba, Cracoviae 1908-1913, s. 52, „Entretiens du roi avec Mr le comte de Stackelberg ambassadeur de Russie avec les affaires traitées par ordre de Sa Majesté avec le même ministre depuis le commencement de janvier jusqu'au 31 décembre 1771".

31 P. Bańkowski, Archiwum Stanisława Augusta, s. 260.

32 Bańkowski nie uwzględnił go w swojej książce, ponieważ w ogóle nie wziął pod uwagę Archiwum Koronnego Warszawskiego jako miejsca, gdzie mogłyby być przechowywane dokumenty wytworzone w królewskim Gabinecie.
} 
nr 9. Odnalezienie dwóch w całości zachowanych czystopisów oraz jednego fragmentu może świadczyć o tym, że z minuty „Entretiens” wykonywano więcej niż tylko jeden odpis. Dlaczego zatem zachowały się tylko te trzy? Odpowiedź nie jest jednoznaczna. Mógł to być przypadek. Możliwe jednak, że czystopis rozmów z 1777 r. został sporządzony w dwóch egzemplarzach, ponieważ pierwszy okazał się wadliwy. Sporządzający go sekretarz nie zauważył, że jedna z kart została umieszczona w minucie w złej kolejności i powielił ten błąd w czystopisie ${ }^{33}$. Z tego powodu sporządził, jak można się domyślać, nowy czystopis, już bez tej wady (nie znamy go). Los czystopisu z 1779 r., a także fragmentu z $1781 \mathrm{r}$. wiąże się z kolei z ostatnim okresem życia Stanisława Augusta, kiedy to król zajęty był redagowaniem pamiętników. W momencie śmierci król pracował nad księgą ósmą, której narracja została przerwana na roku 1778. Nawet pobieżne zestawienie treści „Mémoires” z „Entretiens”, które stanowią kompendium wiedzy o relacjach polsko-rosyjskich, pozwala dostrzec daleko idące zbieżności w układzie tematów podejmowanych przez króla we wspomnieniach z zagadnieniami odnotowanymi w „Entretiens”. Wydaje się - choć z całą pewnością wątek ten wymaga dalszych gruntownych badań porównawczych - że właśnie „Entretiens” króla ze Stackelbergiem stanowiły rodzaj „szkieletu” chronologicznego, który, uzupełniony o dodatkowe materiały, pozwalał wypracować końcowy kształt wspomnień Stanisława Augusta. Przechowywany w AGAD czystopis „Entretiens” z 1779 r. znajduje się w rewindykowanym z Rosji na mocy postanowień traktatu ryskiego z 1921 r. Archiwum Koronnym Warszawskim, a w spisie papierów pozostałych po śmierci Stanisława Augusta sporządzonym przez jego archiwistę Christiana Wilhelma Friesego, które ok. 1801 r. były przechowywane w archiwum rosyjskiego Ministerstwa Spraw Zagranicznych, pod nr. 76 znajduje się adnotacja: „Extraits des correspondances et entretiens 1779 à 1780"34. Można zatem przyjąć, że „Entretiens” z 1779 r. król miał w swoich apartamentach w chwili śmierci z zamiarem użycia go w pracy nad kolejną księgą pamiętników. Najmniej można powiedzieć o rękopisie „Entretiens” z 1781 r., który zachował się jedynie w części. Jego przynależność do Archiwum Królestwa Polskiego świadczy o tym, że rękopis ten wcześniej znajdował się wraz z innymi pokrólewskimi archiwaliami w Moskwie. Pomimo braku adnotacji w spisie Friesego o innych - poza rokiem 1779 - rocznikach „Entretiens” nie można z góry zakładać, że król ich nie miał w Petersburgu.

Jak już wspomniałam, „Entretiens” króla ze Stackelbergiem nie są źródłem o proweniencji literackiej, jak chciał je widzieć Stanisław Wasylewski. Stanowiły one wewnętrzny dokument królewskiego Gabinetu i nic nie wskazuje na to, że były spisywane w celu późniejszej publikacji. Inaczej rzecz się ma z „Mémoires” Stanisława Augusta, które w ośmiu tomach przedstawiają czytelnikowi okres od jego narodzin do końca 1778 r. Dzieło to od początku było pisane z myślą o przyszłym czytelniku ${ }^{35}$. Jak wskazali współcześni wydawcy monarszych pamiętników, nie powstawały one zgodnie z chronologią opisywanych wydarzeń. Król rozpoczął pracę nad nimi najprawdopodobniej tuż po nieudanym zamachu na jego życie w listopadzie $1771 \mathrm{r}$. i wówczas powstał tom trzeci, obejmujący lata 1758-1764. W dalszej kolejności - do końca 1775 r. - powstał tom pierwszy, obejmujący dzieciństwo i młodość przyszłego monarchy, czyli lata 1732-1755. Tom drugi (1755-1758), który zawiera m.in. opis pobytu przyszłego władcy w Petersburgu i jego romans z Katarzyną II, król zredagował zapewne w 1781 r., co może się łączyć z podróżą do Wiśniowca i spotkaniem z wielkim księciem Pawłem, który żywił przekonanie, że mógł być synem Stanisława Augusta. Ponowny kontakt z „dworem rosyjskim na wyjeździe", a zapewne też czas spędzony w podróży, być może natchnęły króla do opisania właśnie wówczas tego jakże barwnego fragmentu jego życiorysu. Po 1781 r. Stanisław August zarzucił pisanie pamiętników aż do 1793 r., kiedy to do końca pobytu w Grodnie (1795-1796) przygotował tomy od czwartego do ósmego. Ostatni sprawia jednak wrażenie niedopracowanego, ponieważ w znacznej części

${ }^{33}$ Rozmowa nr 68 z 7 XII 1777 rozpoczyna się na k. 106v, kończy się zaś na k. 111.

${ }^{34}$ P. Bańkowski, Archiwum Stanisława Augusta, s. 69.

${ }^{35}$ W 2012 r. w Paryżu ukazała się po prawie 100 latach reedycja Mémoires (zob. przyp. 21). Pierwsze wydanie Mémoires, które przygotował do druku S.M. Goriaïnow we współpracy z W. Konopczyńskim i S. Ptaszyckim, ukazało się w dwóch tomach - t. 1 w 1914 r. w Petersburgu (obejmuje lata 1732-1773), t. 2 zaś już po śmierci wydawcy, w 1924 r. w Leningradzie. Druga edycja, sporządzona bezpośrednio z przechowywanego w Moskwie rękopisu, koryguje pewne (nieliczne) uchybienia pierwszej. 
stanowi zlepek różnych dokumentów (listy, diariusz sejmu 1778 r., fragmenty „Entretiens”). Po śmierci Katarzyny II decyzją nowego władcy król został przewieziony do Petersburga (po kilkutygodniowym pobycie w Moskwie podczas koronacji imperatora) i prawdopodobnie tam dalej pracował nad swoimi wspomnieniami, choć właściwsze wydaje się określenie, że była to już raczej historia jego panowania. „Mémoires” kilkakrotnie thumaczono na język polski, choć nigdy nie otrzymaliśmy thumaczenia całości ${ }^{36}$.

Dla każdego badacza korzystającego z pamiętników Stanisława Augusta zasadnicze pozostaje pytanie, ile jest w nich prawdy historycznej, a ile autokreacji. Pomimo 100 lat obecności tego źródła w nauce nie mamy na to pytanie jednoznacznej odpowiedzi. Co więcej, do czasu ukazania się wydania paryskiego analizie ich treści nie poświęcono osobnej pracy. Niedawno ta sytuacja uległa pewnej poprawie. Ukazał się - po pierwsze - zbiór esejów o bohaterach królewskich wspomnień, stanowiących zapis wykładów odbywających się w Łazienkach Królewskich od września 2013 do czerwca 2014 r. ${ }^{37}$ Po drugie, rozprawę o królewskich pamiętnikach przygotowała Teresa Kostkiewiczowa ${ }^{38}$. Pozycja ta jest poświęcona analizie struktury i treści „Mémoires”. Król - jak zauważa autorka - podkreślał, że chce pisać jako historyk. Wiarygodności wspomnień władcy, powszechnie obarczanego winą za upadek państwa, miało służyć zamieszczanie dużych fragmentów źródeł typu dokumentowego, wypełniających zwłaszcza tomy od czwartego do ósmego. Jednak do rzetelnej oceny ich wiarygodność nie wystarcza szczegółowa analiza ich treści, potrzebne jest zestawienie i porównanie ich z innymi źródłami, we wspomnieniach pominiętymi.

„Entretiens” wydają się jednym z najważniejszych typów źródeł, które pozwalają na skonfrontowanie obrazu stworzonego po latach przez króla-pamiętnikarza z rzeczywistością. Szczególnie istotne są zapisy rozmów z rosyjskim ambasadorem, a więc przedstawicielem hegemona polskiego państwa. W rozdziale książki T. Kostkiewiczowej zatytułowanym „Dialog jako forma świadectwa” czytamy: „Zabieg przytaczania [...] dialogów w mowie niezależnej występuje $\mathrm{z}$ większą częstotliwością $\mathrm{w}$ tomach obejmujących czas poelekcyjny, a uczestnikiem rozmów jest głównie król. [...] Pamiętnikarz wprawdzie kreuje niejako zobiektywizowaną sytuację cytowania wypowiedzianych słów, nie kwestionuje ich treści i nie komentuje [...], ale $\mathrm{w}$ istocie to on decyduje o kształcie i treści kwestii włożonych $\mathrm{w}$ ich usta, dążąc do stworzenia aury bezstronności. [...] Trzeba wszakże pamiętać, że omawiane dialogi - mimo iż odnosiły się do przeprowadzanych przez króla konkretnych, zlokalizowanych czasowo spotkań i rozmów w zapisanym kształcie były dokonaną na użytek »Pamiętników« imitacją realnego ich przebiegu. [...] Wydaje się, że wprowadzając dialogi w mowie zależnej w tok własnego wywodu, pamiętnikarz sprawnie osiągał różne cele: przybliżenie i pogłębienie obrazu relacji króla z ambasadorami carycy, wzmocnienie wiarygodności tego obrazu oraz zróżnicowanie i ożywienie własnej opowieści, wzbogaconej kolejnym zabiegiem formalnym, zaczerpniętym ze sztuki dramatycznej”39. Co prawda autorka nie do

36 Pierwszy przekład, a de facto pierwsze wydanie królewskich wspomnień ukazało się w Poznaniu w 1862 r. (w księgarni J.K. Żupańskiego) w postaci dwujęzycznej jako Pamiętniki króla Stanisława Poniatowskiego i jego korespondencyje z cesarzowa Katarzyna II. Są to fragmenty t. 2 (pobyt przyszłego króla w Petersburgu), przesłane niegdyś przez samego autora Mikołajowi Wolskiemu do Białegostoku. Kolejne tłumaczenie autorstwa Bronisława Zaleskiego pochodzi z 1870 r. i zostało opublikowany w Dreźnie przez Józefa Ignacego Kraszewskiego; Pamiętniki króla Stanisława Augusta Poniatowskiego, tłum. B. Zaleski, Biblioteka Pamiętników i Podróży po Dawnej Polsce, t. 3, wyd. J.I. Kraszewski, Drezno 1870. Ta edycja zawiera pierwsze dwa tomy przechowywane w rkps 1703 z BCzart. Kolejnej próby przekładu opartej na dwutomowym wydaniu Goriaïnowa podjęli się Władysław Konopczyński i Stanisław Ptaszycki. Wydali oni część t. 1 edycji petersburskiej - do wyjazdu Stanisława Antoniego z Petersburga w 1758 r.; Pamiętniki króla Stanisława Augusta, t. 1, cz. 1, tłum. W. Konopczyński, S. Ptaszycki, Warszawa 1915. I wreszcie w 2013 r. ukazał się jak dotąd najszerszy przekład pamiętników, z podtytułem Antologia. Wyboru tekstu do tłumaczenia dokonał Dominique Triaire, przełożył Wawrzyniec Brzozowski, wstęp napisała Anna Grześkowiak-Krwawicz, a redaktorem całości był Marek Dębowski. W Pamiętnikach króla Stanisława Augusta. Antologii, wydanej przez Muzeum Łazienki Królewskie, z założenia pominięto wszystkie „wpisane” w pamiętniki dokumenty, takie jak diariusz sejmowy (1778), noty dyplomatyczne, korespondencja dyplomatyczna itp., choć zachowano niektóre prywatne listy króla. Całość ma raczej charakter literacki (stąd podtytuł Antologia) niż dokumentacyjny.

37 Pamiętniki Stanisława Augusta i ich bohaterowie, red. A. Grześkowiak-Krwawicz, Warszawa 2015.

38 T. Kostkiewiczowa, Pamiętniki Stanisława Augusta na nowo odkryte, Studia i Materiały. Zamek Królewski w Warszawie, t. 4, Warszawa 2015.

39 Tamże, s. 125 n., 131. 
końca słusznie założyła, że przytoczone w „Mémoires” rozmowy króla ze Stackelbergiem były późniejszym o prawie dwadzieścia lat wytworem królewskiej wyobraźni, a nie odpisem z relacji ze spotkania, powstałej tuż po jego zakończeniu, ale wnioski o kreowaniu czy upiększaniu przez monarchę rzeczywistości nie są pozbawione racji. Stanisław August nawet wtedy, gdy sięgał po zapisy rozmów sprzed wielu lat, na użytek „Mémoires” dokonywał w nich drobnych zmian, które mogą być ważne dla oceny wiarygodności tego dzieła. Duże fragmenty np. diariuszy sejmowych, które król umieścił w historii swojego panowania, mogły być przez uważnego czytelnika szybko zweryfikowane, lecz „Entretiens” nie były znane szerszemu gronu odbiorców i stąd łatwość dokonywania zmian.

Porównanie treści „Mémoires” i „Entretiens” pozwoliło wyodrębnić trzy duże fragmenty zawierające relacje z rozmów króla ze Stackelbergiem. Są to przede wszystkim spotkania z 29 IX $1777^{40}$ i 19 października tego roku ${ }^{41}$ - obydwa wymienione fragmenty już w „Entretiens” zapisane były w formie dialogu, zwróciły one uwagę T. Kostkiewiczowej. W innym miejscu włączono do pamiętników w nieco zmodyfikowanej formie 14 kolejnych dat/numerów „Entretiens” od 21 (nr 114) do 30 X 1778 r. (nr 127) ${ }^{42}$. Jednak o wiele ciekawsza z punktu widzenia badacza próbującego ocenić wiarygodność „Mémoires" jest rozmowa z 21 IX 1778 r., której król nie skopiował z „Entretiens”, lecz wykorzystał znajdującą się tam szczegółową relację do napisania własnej, dialogowanej wersji ${ }^{43}$. Pociągnęło to za sobą pewne zmiany, których analiza pozwala uchwycić ślad zamysłu, jakim kierował się Stanisław August przy redagowaniu „Mémoires”. Powiedzmy z góry, że mamy do czynienia ze swego rodzaju autocenzurą. Warto sprawdzić, jakich kwestii ona dotyczyła.

W przeważającej części napisany przez króla dialog jest wiernym powtórzeniem tak treści, jak i kolejności spraw omawianych z ambasadorem 21 IX 1778 r. W niektórych miejscach Stanisław August pominął wątki rozbijające narrację i zaburzające klarowność wywodu. Na przykład w części rozmowy dotyczacej obsady funkcji marszałka zbliżającego się sejmu król pominął fragment, w którym Stackelberg wspomniał o tym, że rozmawiał z marszałkiem wielkim koronnym Stanisławem Lubomirskim zapewne w tym kontekście o Łączyńskim. Wydaje się, że chodziło o ówczesnego łowczego gostyńskiego Macieja Łączyńskiego, który w 1778 r. posłował z ziemi gostyńskiej ${ }^{44}$. Ponieważ w dalszej części rozmowy króla z ambasadorem spierano się, czy marszałkiem sejmu ma zostać Kazimierz Wolmer, czy też ówczesny pisarz wielki litewski Ludwik Tyszkiewicz, to wprowadzenie dodatkowej osoby do dialogu wymagałoby dodatkowych wyjaśnień, a te nie służyłyby klarowności wywodu. Czasami Stanisław August dodawał wyjaśnienia z myślą o czytelniku mniej zorientowanym w sprawach polskich, jak w przypadku informacji o zabiegach Kacpra Rogalińskiego o województwo brzesko-litewskie, które ten chciał wymienić z Janem Tadeuszem Zybergiem na województwo inflanckie. W tym miejscu król dopowiedział ponad to, co znajduje się w „Entretiens”, że każda osoba zabiegająca o stanowisko wojewody powinna posiadać własność ziemską w województwie, o którego kierowanie się ubiegała ${ }^{45}$. Król dodawał w „Mémoires” informacje, których nie znajdziemy „Entretiens”, i tak w obydwu źródłach mamy przekaz, że August Sułkowski nie zamierzał starać się o trzecią kadencję w Radzie Nieustającej (trzeba dodać, że wbrew prawu, gdyż zgodnie z nim mógł w niej zasiadać tylko przez 2 kadencje) m.in. dlatego, że nie miał środków, aby mieszkać w Warszawie odkąd zabrano mu dzierżawę czopowego. Jedynie z pamiętników możemy się dowiedzieć, że za odebraniem owej dzierżawy stał marszałek wielki

${ }^{40}$ BPAU/PAN, sygn. 1649, „Entretiens”, nr 49, k. 100v-102; Stanislas Auguste, Mémoires (2012), s. 698-700.

${ }^{41}$ BPAU/PAN, sygn. 1649, „Entretiens”, nr 57, k. 103-104; Stanislas Auguste, Mémoires (2012), s. 700 n.

${ }^{42}$ BPAU/PAN, sygn. 1649, „Entretiens”, k. 145-149; Stanislas Auguste, Mémoires (2012), s. 771-776.

${ }^{43}$ BPAU/PAN, sygn. 1649, „Entretiens”, nr 89, k. 134-137; Stanislas Auguste, Mémoires (2012), s. 728-733.

44 R. Chojecki, Łaczyński Maciej, w: PSB, t. 18, Wrocław 1973, s. 316-317.

${ }^{45}$ Stackelberg pierwsze zabiegi o zapewnienie Rogalińskiemu miejsca w senacie podjął już w 1775 r. Początkowo miało to być woj. czernihowskie (BPAU/PAN, sygn. 1649, „Entretiens”, nr 50, 7 XI 1775, k. 58), ponowił swoją prośbę 26 XI 1776 (tamże, k. 85v). W listopadzie 1776 r. ambasador domagał się od króla pisemnego zapewnienia, że Rogaliński otrzyma pierwszy urząd senatorski, który zwolni się w Wielkopolsce (tamże, k. 87), w maju 1778 r. żądał zaś, aby król obdarzył woj. brzesko-litewskim Zyberga, Rogalińskiego natomiast inflanckim (tamże, k. 120). Wobec odmowy władcy ambasador chciał wymusić woj. brzeskie dla Rogalińskiego (tamże, k. 122), w czerwcu król odmówił (tamże, k. 124). Dopiero rozmowa z 21 września i rzucenie na szalę argumentu przyjaźni imperatorowej przyniosły oczekiwany przez Stackelberga skutek. 
koronny Stanisław Lubomirski ${ }^{46}$. Z zabiegami o krzesło senatorskie dla Rogalińskiego łączy się też wątek szczególnego traktowania Katarzyny II w „Mémoires” - sprawa niewątpliwego „wymuszenia” dokonanego na królu przez ambasadora (notabene wszystko zostało załatwione zgodnie z prośbą ambasadora już 3 X 1778) jest opisana w trochę bardziej złagodzonej formie, niż to było w rzeczywistości: zamiast zdania z „Entretiens”: „le roi déclare à l'ambassadeur que si l'amitié de l'impératirce est à ce prix, Rogaliński sera palatin”, monarcha na użytek „Mémoires” spuentował rozmowę zdaniem: „s’il faut cela pour plaire à l'impératrice, Rogaliński sera palatin". Czy przyjaźń Katarzyny II warta była ceny, którą w tych i innych okolicznościach płacił Stanisław August? Trzeba pamiętać, że nawet jeśli omawiany awans wynikał tylko z ambicji Stackelberga i gry o swą klientelę, a Petersburg nic o sprawie nie wiedział, to i tak władca państwa tak głęboko uzależnionego od Rosji nie mógł ryzykować narażenia się na zemstę czułego na punkcie swej władzy ambasadora, którego ewentualne nieżyczliwe czy wręcz oszczercze relacje słane nad Newę mogły Polskę drogo kosztować. Na marginesie można dodać, że słowa „amitié” czy ,amie” w ustach rosyjskiego dyplomaty w odniesieniu do stosunku jego samego i jego władczyni wobec polskiego króla były bodaj najczęściej pojawiającymi się w „Entretiens”.

W sposób bardzo przemyślany Stanisław August przedstawił w pamiętnikach wątek Piotra Maurycego Glayre'a związany ze stosunkowo znaną sprawą portretu Katarzyny II. Szwajcar portret ów widział na dworze Fryderyka Wielkiego w Berlinie, zawieszony na tapiserii przedstawiającej scenę wyrzucenia przekupniów ze Świątyni Jerozolimskiej. Obraz imperatorowej został umieszczony w taki sposób, że wydawało się, jakby Chrystus biczem mierzył w carycę ${ }^{47}$. Przenosząc tę anegdotę do swoich wspomnień, król pominął dwie rzeczy. Po pierwsze, informację o bardzo aktywnej roli samego Glayre’a w rozgłaszaniu tej opowieści. Zgodnie z wersją z „Mémoires” rzecz doszła do uszu ambasadora trochę na zasadzie „plotkarskiej”; Glayre miał ponoć zwrócić na to uwagę, bawiąc jeszcze w Paryżu w gościnie u rosyjskiego ambasadora przy francuskim dworze, ks. Iwana Sergiejewicza Bariatinskiego, i stamtąd miał się o sprawie dowiedzieć Stackelberg. W „Entretiens” ambasador podkreślał natomiast, że Glayre nie tylko w Paryżu, lecz również w Warszawie dzielił się powszechnie swoimi spostrzeżeniami i to w jego - rosyjskiego przedstawiciela - obecności. Zatem w ocenie Stackelberga Glayre miał z premedytacją szkodzić wizerunkowi Katarzyny II, i to nie gdzieś w Paryżu, ale pod bokiem ambasadora w Warszawie. Tę wylewność Glayre'a w rozpowszechnianiu szyderczej wobec z Katarzyny II anegdoty król w „Mémoires” pominął. Ponadto zamieszczona tam wypowiedź Glayre’a została niejako „rozmyta” - to, co miał zobaczyć w Berlinie wyglądało jakoby Chrystus celował w carycę, a w „Entretiens” tego celowego domniemania użytego w „Mémoires” nie ma. Stanisław August być może dokonał tej zmiany z myślą o tych, którzy mogli zablokować publikację pamiętników i starał się unikać fragmentów mogących godzić nawet w najmniejszym stopniu w osobę Katarzyny II. Przy okazji zmniejszył też ciężar zarzutów, jakie pod adresem Glayre’a kierował ambasador i przedstawił tego ostatniego jako osobę nad wyraz drażliwą, która przejmuje się jakimiś rozsiewanymi aż w Paryżu plotkami ${ }^{48}$.

Zresztą król nie tylko w tym miejscu przedstawił ambasadora jako osobę dość trudną w kontaktach osobistych. W dalszej części rozmowy z 21 IX 1778 Stanisław August uzupełnił jej zapis o małe złośliwości pod adresem Stackelberga. W „Mémoires” monarcha wspomniał, że Glayre zaproponował, iż usunie się z warszawskiego dworu, aby nie być powodem ciągłych uwag ambasadora i czynionych królowi w związku z tym różnych przykrości, ambasador miał wówczas zaprotestować słowami: „Son éloignement jetteroit un ridicule sur moi”, król zaś dopowiedział w nawiasie: „le ridicule que Stackelberg craignoit étoit qu'on ne le crut jaloux à cause d'une jeune dame qu'il courtisoit" ${ }^{\text {"49. }}$. Dama ta zapewne bar-

\footnotetext{
46 Stanislas Auguste, Mémoires (2012), s. 731.

47 Tamże, s. 728; BPAU/PAN, sygn. 1649, „Entretiens”, nr 89, k. 134v. Ostatnio epizod ten z punktu widzenia opisu zamieszczonego w pamiętnikach przedstawił Piotr Ugniewski w artykule Francuzi i francuskość w „Pamiętnikach” Stanisława Augusta, w: Pamiętniki Stanisława Augusta i ich bohaterowie, s. 212.

48 Wizerunkowi rosyjskich ambasadorów, w tym Stackelberga, w „Mémoires” osobny artykuł poświęciła Dorota Dukwicz: Kontakty Stanisława Augusta z ambasadorami Katarzyny II w Warszawie w świetle „Pamiętników” królewskich, w: Pamiętniki Stanistawa Augusta i ich bohaterowie, s. 265-291.

49 Stanislas Auguste, Mémoires (2012), s. 728.
} 
dziej łaskawym okiem patrzyła na Glayre’a. Wspomnianego wątku nie znajdziemy w „Entretiens”, gdzie Stackelbergowi pomysł, aby Glayre odszedł ze wspomnianego wyżej powodu wydał się śmieszny bez dodatkowych podtekstów: „l'ambassadeur avec inquiétude demande que Mr Glayre ne soit pas éloigné, que ce serait un ridicule pour lui" ${ }^{50}$. Z całą pewnością z pamiętników wyłania się obraz Stackelberga jako osoby małostkowej, kierującej się uprzedzeniami i zazdrością oraz wykorzystującej swą pozycję do nękania polskiego króla. Nie mamy przy tym pewności, czy uczuciowe współzawodnictwo Glayre’a i Stackelberga miało rzeczywiście w owym czasie miejsce, czy też zostało wprowadzone tutaj, by bardziej zdeprecjonować osobę ambasadora.

Kolejna różnica pomiędzy treścią „Entretiens” i „Mémoires” dotyczy fragmentu, w którym rozmowa zeszła na temat zbliżającego się sejmu - jego organizacji, a zwłaszcza osoby przyszłego marszałka. W pamiętnikach ten problem został okrojony o szczegóły, które podkreślały irytację Stackelberga wywołaną tym, że król nie poinformował go o chęci postawienia na czele sejmu Kazimierza Wolmera. Choć taki zarzut dobrze wpisywałby się w negatywny obraz ambasadora tworzony przez Stanisława Augusta, monarcha wolał go pominąć. Nie wspomniał też, że przygotowana przez podskarbiego nadwornego litewskiego Antoniego Tyzenhauza i jego stronników lista kandydatów do poselstwa została wcześniej - z inicjatywy władcy - przesłana ambasadorowi. Choć ta informacja dowodziła bezzasadności uwag ambasadora, jakoby król nie wtajemniczał go w swoje polityczne plany (to częsty zarzut stawiany królowi przez Stackelberga w „Entretiens”) $)^{51}$, w obu opisanych wypadkach intencją Stanisława Augusta było, jak się wydaje, ukrycie faktu, że król sam z własnej inicjatywy konsultował listę kandydatów do poselstwa z ambasadorem, który za oczywisty uznawał też swój decydujący głos w sprawie wyboru marszałka sejmu. Wszystko to ujawniałoby zakres politycznego uzależnienia monarchy od rosyjskiego dyplomaty, czego we wspomnieniach król wolał, jak się wydaje, nie eksponować.

W niektórych miejscach król dosłownie koloryzuje, pisząc, że ambasador „zaczerwienił się”. Takie uwagi oddające wygląd i stan emocji interlokutora zamieszczał król wielokrotnie na kartach „Entretiens”. Zapewne obcując z nim prawie codziennie przez 18 lat, znał doskonale cały katalog „ostatecznych" argumentów dyplomaty, do których ten dołączał odpowiednią minę czy gest. Nie jest więc zapewne dużą nieścisłością, gdy król opisuje styl Stackelberga jako przesadnie napuszony, emfatyczny, gdy ambasador naciskał na niego, używając argumentu, iż przemawia „en qualité d'ambassadeur de la meilleure amie du roi".

Najważniejszy może z pominiętych w pamiętnikach fragmentów z „Entretiens” dotyczy kwestii związanych z pozycją króla wobec narodu z jednej, a Rosji z drugiej strony. Stackelberg rozpoczął od zarzucania królowi, że „zły macie - a nawet odrażający - system polityczny, bo wciąż pracować musicie nad tym, ażeby mocne utrzymać stronnictwo w każdym województwie, co partyjnego ducha ożywia w całym kraju [...]. Skutek tego jest taki, że przy procesach i promocjach nikt się nad zasługami człowieka nie zastanawia, tylko pyta, z jakiej też partii pochodzi”. Król replikował przypomnieniem genezy stronnictwa regalistycznego: „Sto razy już mi powtarzałeś od czasu rozbioru [...], że [...] to we mnie należy widzieć głowę stronnictwa rosyjskiego w Polsce, która już więcej wicekróla nie potrzebuje, a szczególnie nie powinien to być żaden z Czartoryskich. [...] Zgodziłeś się, żeby to wokół mej osoby skupiali się w każdym powiecie i żebym awansów oraz łask odmawiał ludziom, którzy przeciwko mnie staną w sejmie i podczas sejmików. [...] Tak mocno nalegałeś, abym przyjął system, który teraz »odrażającym« nazywasz, żem się do tego w końcu dostosował - i myślę teraz, że dobrze zrobiłem, bo tego roku, kiedy Rosja ani pieniędzy, ani wojsk podczas sejmików nie użyła, trzy czwarte posłów po naszej obrano myśli. Przypominam ci atoli, że kiedy w nocy z 3 na 4 listopada 1771 roku pytanie zadałem mojemu mordercy, czemu pragnie mnie życia pozbawić, ów odrzekł: »Boś jest, panie, Rosji przyjacielem«". Dalszy fragment wymówek Stackelberga odnosił się do nadmiernej władzy i nadużyć na Litwie Tyzenhauza oraz przemęczania się króla korespondencją z poddanymi, nielicującą podej-

${ }^{50}$ BPAU/PAN, sygn. 1649, „Entretiens”, nr 89, k. 134v.

51 Tamże, k. $135-135 \mathrm{v}$. 
mowaną tematyką z godnością tronu ${ }^{52}$. W „Entretiens” fragment ten jest szerszy. Po krytyce ze strony Stackelberga „złego” czy wręcz „odrażającego” systemu politycznego, podtrzymującego „ducha partii” i replice króla, że to ambasador sugerował po rozbiorze, iż monarcha winien być szefem partii rosyjskiej, „wicekrólów” zaś, czyli Czartoryskich, trzeba wykluczyć, Stanisław August przypomniał, że w tym kontekście uprzedzał dyplomatę, a ten się z tym zgodził, iż musi to oznaczać posiadanie przez władcę w poszczególnych powiatach zasłużonych ludzi i nagradzanie wiernych kosztem oponentów. Mimo że król zaczął konsekwentnie wdrażać ten plan, ,à la diète de 1775 et de [17]76 l'ambassadeur a fait durement entendre au roi qu'il n'était point aimé, qu'il n'avait point d'amis [podkr. w oryg.]. Sur quoi le roi observe que dans la nuit affreuse du 3 au 4 novembre 1771 quand il avait demandé à son assassin pourquoi il avait voulu lui ôter la vie, il avait répondu : parce que vous êtes ami des Russes [podkr. w oryg.]. Depuis ce temps le roi a répété à l'ambassadeur qu'on commence à terminer sans rigueur ce qui regarde les gens de Bar, et qu'il n'y ait pas de nouveaux troubles, et alors il assure que l'on lui verrait après des amis et un parti, cela s'est vérifié, puis que dans cette année 1778 où la Russie n'a pas donné le moindre subside, où les soldats [k. 137] russes n'ont pas été employés dans les diétines, les trois quart de ces diétines ont réussis au gré du roi, cela prouve donc que la méthode qu'il a employé était bonne" 53 . Jak widać, w „Mémoires” Stanisław August usunął dwie rzeczy: informację o zarzutach ambasadora, że podczas sejmów lat 1773-1775 i 1776 nie cieszył się miłością swych poddanych i nie dysponował społecznym zapleczem oraz to, że osobiście zabiegał o oszczędzenie eksbarzanom szykan, widząc w tym ważny czynnik uspokojenia kraju i stworzenia warunków, w których możliwe było zbudowanie królewskiego stronnictwa. Zwycięstwo regalistów na sejmikach poselskich w 1778 r. stanowiło dowód słuszności królewskich założeń, Stanisław August wyraźnie jednak unikał przywoływania tych momentów ze swojego panowania, gdy jego postawa i oczekiwania społeczeństwa w sposób wyraźny się rozmijały.

Kilka opisanych wyżej rozbieżności pomiędzy treścią „Mémoires” a zapisami znajdującymi się w „Entretiens” Stanisława Augusta z Ottonem Magnusem von Stackelbergiem z całą pewnością nie pozwala na pełną ocenę wiarygodności królewskich memuarów. Wskazuje jednak z jednej strony na kierunki, w jakich król nieco swe wspomnienia podkoloryzowywał, z drugiej zaś podtrzymuje opinię o ich zasadniczej wiarygodności. Kluczowym dowodem tej ostatniej jest związek pamiętników z niezwykle ważnym źródłem, jakie stanowią „Entretiens”. W moim przekonaniu nie tylko w miejscach wyżej wskazanych były one podstawową pomocą dla króla przy redagowaniu „Mémoires”, lecz stały się od pewnego momentu rodzajem szkieletu chronologicznego wspomnień.

Fakt, że udało się odnaleźć w materiałach rewindykowanych z Rosji jeden w całości zachowany czystopis „Entretiens” oraz drugi fragmentaryczny i nieujęty w spisie Friesego pozwala mieć nadzieję, że w archiwach rosyjskich uda się dotrzeć do kolejnych tomów „Entretiens” Stanisława Augusta ze Stackelbergiem z lat 1780-1789. Już wiedza o tym, że tworzono więcej niż jedną kopię czystopisu „Entretiens”, czego dowodzą te z nich, które zachowały się w Bibliotece Czartoryskich i AGAD, pozwala liczyć na pozytywny efekt dalszych poszukiwań. Ich odnalezienie pozwoliłoby lepiej poznać politykę prowadzoną przez Stanisława Augusta w latach 80. XVIII w. i z całą pewnością zrekompensowałoby brak dla tego okresu zapisków pamiętnikarskich króla.

\section{Entretiens of King Stanislaus Augustus with Russian ambassador Otto Magnus von Stackelberg, and Memoirs of the Commonwealth's last king}

Summary: Among the most important historical sources for the reign of Stanisław August one should list Entretiens abbreviated notices of Stanisław August's talks with the Russian Ambassador Otto von Stackelberg. This article approaches the structure, the state of survival, the date of composition and the authorship of the Entretiens as well as their content and the nature of information included.

\footnotetext{
52 Wszystkie przetłumaczone na j. polski fragmenty za: Pamiętniki króla Stanisława Augusta. Antologia (zob. przyp. 36), S. 505-508.

${ }^{53}$ BPAU/PAN, sygn. 1649, „Entretiens”, nr 89, k. 136v-137.
} 
The Entretiens, firstly conceived as short notes, evolved into more and more complex and specific reports, so the king could easily find every essential piece of information about Polish-Russian relations in one place.

Some of the talks recorded in the Entretiens were later included in King's Memoirs, hence the second part of this article attempts at a comparison between the two. It reveals that the order of events described in Memoirs agrees with what we find in Entretiens, therefore we know that the latter was exploited during the composition of the Memoirs.

The author of the present study was lucky to have found among the documents reclaimed from Russia a clean copy of Entretiens from 1779, which allows us to hope that in Russian archives there are still even later the yearbooks, which supposedly might have helped the King in the work on other volumes of Memoirs. Moreover, the author's intention was to suggest a method which would allow to evaluate reliability of the Memoirs. Owing to a partial comparative analysis of both sources one can conclude that the king wanted to protect his loved ones from being seen as anti-Russian and to avoid criticism of Catherine II. Stackelberg was the only one described exactly as how the king knew him. However, it does not undermine reliability of the Memoirs in general.

Nota o Autorze: Dr Ewa Zielińska, adiunkt w Zakładzie Badań Źródłoznawczych i Edytorstwa Instytutu Historii im. Tadeusza Manteuffla PAN. Specjalizuje się w edycji źródeł do dziejów panowania Stanisława Augusta: współwydawca, wraz z A. Danilczykiem, dwóch tomów korespondencji Stanisława Augusta z Augustynem Debolim (w przygotowaniu tom 3 obejmujący rok 1782), oraz wraz z D. Dukwicz Entretiens du roi Stanislas-Auguste avec Otto Magnus von Stackelberg (1773-1775), Warszawa 2017.

Author: Ewa Zielińska, PhD, assistant professor at the Department of Source Criticism and Editing at the Institute of History, Polish Academy of Sciences. She specialises in the edition of sources on the history of King Stanislaus Augustus' reign; she is the co-editor - together with A. Danilczyk, of two volumes of correspondence exchanged between King Stanislaus Augustus and Augustyn Deboli (a volume three, spanning the year of 1782, is in preparation), and the co-editor with D. Dukwicz of the Entretiens du roi Stanislas-Auguste avec Otto Magnus von Stackelberg (1773-1775), Warsaw, 2017.

Instytut Historii im. Tadeusza Manteuffla PAN

Rynek Starego Miasta 29/31

00-272 Warszawa

e-mail: ewa_zielinska1@op.pl

\section{Bibliografia}

\section{Źródla}

Pamiętniki króla Stanisława Augusta. Antologia, wybór D. Triaire, tłum. W. Brzozowski, wstęp A. Grześkowiak-Krwawicz, red. M. Dębowski, Warszawa 2013

Stanislas Auguste, Mémoires, wyd. A. Grześkowiak-Krwawicz, D. Triaire, Paris 2012

\section{Opracowania}

Bańkowski P., Archiwum Stanisława Augusta. Monografia archiwoznawcza, Warszawa 1958

Kostkiewiczowa T., Pamiętniki Stanisława Augusta na nowo odkryte, Studia i Materiały. Zamek Królewski w Warszawie, t. 4, Warszawa 2015

Pamiętniki Stanistawa Augusta i ich bohaterowie, red. A. Grześkowiak-Krwawicz, Warszawa 2015

Rostworowski E., Edukacja ostatniego króla (1765-1772), w: tenże, Popioły i korzenie. Szkice historyczne i rodzinne, Kraków 1985, s. 61-73 